\title{
10. A Century of Dissonance and Harmony in Swedish Intoxication Policy
}

Johan Edman

As so many times before in the last 50 years, the Swedish parliament has, in the course of the last parliamentary year, called for tougher sentencing and increased coercive measures as a means of dealing with the drug problem (Edman 2019). The liberal-conservative Moderate Party legal policy spokesperson has opined that the penalties for drug dealing be doubled, and the statement of government policy read out by the Social Democratic Prime Minister in January 2019 pledged stricter penalties for those handing over drugs to others (Swedish Radio 5/I 2 20I 8; Statement of Government Policy 2I/I 2019).

The repressive policy on drugs makes a striking contrast with an increasingly liberal alcohol policy. For example, in the spring of 20I8, a parliamentary majority expressed for the first time its support for the direct sales of alcohol by producers, which a public enquiry had previously found to constitute an immediate threat to the Swedish alcohol retailing monopoly Systembolaget (Parliamentary Records [PR] 20I7/I 8:IO7, $\mathbb{I}$ I4; SOU 2009:22). The reform is deemed to be so urgent that it was addressed in one of the 73 policy proposals of the so-called January Agreement between the Social Democrats, the Green Party, the Liberals and the Centre Party in January 2019 (Utkast II/I 20I9).

The examples follow a clear post-war trend: while the drug political measures have grown more stringent - or have at least retained their severity - the alcohol policy has become ever more

How to cite this book chapter:

Edman, Johan. A Century of Dissonance and Harmony in Swedish Intoxication Policy. In: Retreat or Entrenchment? Drug Policies in the Nordic Countries at a Crossroads, edited by Henrik Tham, 239-265. Stockholm: Stockholm University Press, 202I. DOI: https://doi.org/IO.I6993/bbo.j. License: CC BY 4.0. 
liberalised. By discussing the dissonance within the Swedish intoxication policy - both between alcohol and drug policies, and between the conceptual understanding of intoxication problems and the implemented intoxication policies - I seek to promote a greater understanding of the current alcohol and drug policies. The examples come from the societal debate on and management of intoxication in Sweden over the last Ioo years, and the study is empirically based mainly on official reports and parliamentary material. By way of conclusion, I will speculate about the direction of the intoxicant policy in the future..$^{5}$

Let me first introduce a conceptual definition and make a demarcation. Intoxicant policies do not necessarily problematise the consumption of intoxicants or propose that they be restricted or banned. In Sweden, alcohol has been the subject of government regulation at least since King Gustav Vasa prohibited the manufacture of spirits in the mid I 500 s based on arguments that mainly stemmed from the state-builder's national economic vision: the grain was to be preserved for food only. The sparse alcohol political measures during the following 300 years serve to illustrate various government objectives. The national economy, at times questions of public order, but most of all the state needs for revenue from the manufacturing or monopoly taxes on spirits, have taken centre stage. For example, when Queen Kristina introduced the first manufacturing taxes on spirits in 1638 it was in aid of the state's coffers. The plans of prohibiting the distilling of spirits for home consumption in I7I 8 were also the result of the need to strengthen the public finances in a country almost ruined by the wars of King Karl XII (Edman 20I6a).

The focus here is on what I have chosen to call the Swedish intoxication policy. This refers to the public and political discussions about and proposals to solve problems that arise from intoxication from narcotic preparations and/or alcohol. Intoxication policies can cover phenomena explained by intoxication, such as

${ }_{58}$ This chapter is a revised version of the previously published contribution in the yearbook of the Riksbankens Jubileumsfond, The Swedish Foundation for Humanities and Social Sciences: Edman, J. (2019). Drogerna: den nya berusningspolitiken. In J. Björkman \& P. Hadenius (Eds.), Det nya Sverige, Göteborg \& Stockholm. 
ill health or intoxicant-related mortality, or pertain to a dependence on an intoxicant irrespective of other consequences. While the lamentable effects of intoxication are an indirect point of departure in intoxication political measures, these policies can also come down to entirely different things (Yokoe 20I9). Most questions lend themselves to being used in intoxication policies and, as we shall see, a range of societal issues have been discussed with intoxication as a political tool.

\section{Alcohol Political Prologue}

As alcohol has been the culturally and historically established intoxicant, it is possible to trace descriptions of intoxication political problems far back in time. For example, the Book of Proverbs (compiled in the sixth century BCE) of the Old Testament contains stories about the dangers of kings' drunkenness: 'lest they drink and forget what has been decreed, and deprive all the oppressed of their rights' (Book of Proverbs 3 I:5). What follows a few lines down is the image of less fortunate people that 'drink and forget their poverty and remember their misery no more' (Book of Proverbs 3 I:7). These two early examples of intoxication policy crop up regularly when intoxication is to be illustrated. It is in these terms that Friedrich Engels (I 845), for example, discusses the role of alcohol as an escapist consolation in his study on the condition of the working class in England. The two Biblical stories represent viable mental models even today: the former could be translated into a harm to others approach, much discussed in the field of substance abuse research, while the latter could be characterised as a symptom theoretical model that extends the intoxication policy into the realm of general welfare policy (Edman 20I6b).

Popular images of the darker sides of drunkenness, such as those illustrated by William Hogarth's well-known diptych Beer Street and Gin Lane, took shape in mid-eighteenth-century legislative controls, which specifically intended to curb drunkenness and its consequences (Hogarth's I 75 I print was in direct support of the Gin Act from the same year). From the late eighteenth century onwards, such controls aiming at behavioural modification were complemented by a medical problem description, which has 
exerted varying degrees of influence ever since. In their publications, the American physician Benjamin Rush (late I 700s), the British physician Thomas Trotter (early I 80os) and the Swedish doctor Magnus Huss (mid I 80os) talk about the disease of alcoholism as a defect which causes a sprain of the free will and stops the alcohol-abusing individual from making rational decisions (Levine I978; Lundquist I983; McCandless I984; McLaughlin I989; White 2004; Williams I987).

From the mid I 800 s, the religious, moral and medical opposition to alcohol consumption met under the auspices of the growing temperance movement. This transnational movement, which had both political and scientific aims, had considerable influence over national alcohol legislation and knowledge production in the field (Schrad 2007). Here, the alcohol question appears as a kind of litmus paper of modernity, where a variety of societal drawbacks were connected to the consumption of alcohol. The breadth of how the alcohol problem was constructed during the decades around the turn of the nineteenth and twentieth centuries was remarkable. Drunkenness was considered a problem in working life, within the armed forces and in traffic. The moral decay among youth was caused by alcohol, women's drinking and the threat of degeneration were connected, while female sobriety was seen as a role model. Answers were sought far and wide, from total prohibition and strict controls on alcohol sales to social reforms and sterilisations (Edman 20I5; 20I6c).

It is, however, at the beginning of the twentieth century that we encounter more comprehensive alcohol political programmes. The First World War hastened the development that the temperance movement had worked for, and many countries now introduced or tightened their alcohol control systems (Schrad 20I0). Several countries instituted alcohol bans of some sort during or after the First World War; in addition to Russia and the United States, three Nordic countries did so too: Finland, Norway and Iceland (Edman 20I8).

Total prohibition was also discussed in Sweden as the solution to alcohol consumption, which according to one of many investigative committees led to 'unhappy family situations, poverty, crime, disease, degeneration and neglect of the children' 
(Fattigvårdlagstiftningskommittén I9II). The solution came in I9I9 in the form of a rationing book (motbok), which regulated the selling of alcohol to individuals. Diligent citizens were given a motbok of their own and were allocated a controlled amount of spirits depending on their class and sex. At around the same time, Sweden also adopted treatment legislation with a focus on coercion and resocialisation.

We should note that there was a connection between the motives underpinning the politics. For example, according to the architect of the motbok, Ivan Bratt, who also had a great influence on the new legislation on compulsory care, people who were ill 'should be treated gently, but when it comes to alcoholics, one ought to be strict, and if one should on occasion raise one's hand against them, such heavy-handedness would not be out of place' (Alkoholismen I927). Bratt's approach was characteristic of the Swedish alcohol political solution: the abuse of alcohol was not a disease, alcohol was not a poison, and the alcohol question should be tackled with rationing and education rather than by a total ban. This social and non-medical description of the problem was made more concrete in compulsory care, which would restore men to being diligent workers and breadwinners, and women to being virtuous wives and good mothers. The pre-war guiding light of the transnational temperance movement - hard work and the sanctity of family life - was exemplified by an expanding national action programme in the inter-war years (Edman 2004).

The focus of alcohol policy on social problems was challenged in the years following the Second World War. In the wake of, for example, the American alcoholism movement and the public opinion at home for a more humane treatment of alcohol abusers, arguments found their way onto the political agenda and into the public debate in favour of a medical understanding of the alcohol question (Edman 2020). Already in 1944, the Communist Party Members of Parliament Set Persson and Hilding Hagberg penned a motion and expressed their outrage at the fact that there were no medical resources to cure the alcohol abusers: 'alcohol legislation talks about "disease" and "treatment", but in practice converts these concepts into "crime" and "punishment" (Lower House Parliamentary Bill I944:3 I0). Over the next few years, the 
disease status of alcohol abuse was discussed intensely, and the I946 enquiry into the treatment of alcohol abuse made every effort to support the medical approach. The expectation was that a more medical view on alcohol abuse would lead to less repressive treatment (SOU I948:23). The publication of the committee report was followed a few months later by the launch of the medical product Antabuse (disulfiram), which was expected to be the miracle cure that would change the perception of alcohol abuse and the way to treat it. It did not happen; soon the enthusiasm gave way to composed disappointment, and so one returned to the sobering pragmatism that had characterised compulsory care since the I9IOs. Because doctors could not guarantee that alcohol abusers would get well, coercive measures could not be justified by the need for treatment.

But a seed had been sown, and the alcohol political reform of I95 5 shifted the alcohol political motives further and wider. The rationing book was abolished at the same time as a more articulated treatment approach gained ground, and a more extensive search for the causes of the abuse - beyond the individual - also served to make the question ever more political. In 1967, a public enquiry into the care of alcohol abusers submitted its report with a fully-fledged symptom theoretical perspective: abject living conditions explained alcohol abuse rather than the other way around (SOU I 967:36; SOU I967:37). This was also the year that a social services commission was appointed to examine the social service sector in Sweden as a whole, including the care of intoxicant abusers (SOU I974:39; SOU I977:40). This group now encompassed drug users, too.

\section{Drug Repression and Alcohol Liberalisation}

The drug issue gave rise in the I960s to the formation of a new field of intoxication policy based on a rather different problem description. The I960s were a turbulent time in terms of social policy, with an expanding welfare state and criticism in the face of residual poverty. A wide spectrum of issues, from substance abuse to class-based injustices, were investigated and fiercely debated. This made it possible to frame the drug problem in different, and discordant, ways. 
In addition to the social services enquiry, a commission was appointed to investigate the very matter of drug problems, which the commissioners did in four reports covering over I 400 pages (SOU I967:25; SOU I967:4 I; SOU 1969:52; SOU I969:53). A key question addressed was whether drug abuse could be seen as a disease or as a rational response to a dysfunctional and exclusionary society. The debate on social policy that was initiated and discussed by the social services enquiry and the commission on the care of drug users testifies to the complex nature of the question. First of all, we can detect in the I960s a considered notion of the pressing craving as a kind of disease. This conceptual model, adopted from centuries-old argumentation on alcohol abuse, put all intoxicants on an equal footing as a result of their addictive nature. Secondly, drug problems lacked an effective cure, which could have clearly placed drug use within the medical domain. And thirdly, the issue was raised at a time when the treatment of alcohol abusers had come under fire from many different directions and when the efforts for democratic and, potentially, medical care were seen as an opportunity to ameliorate the oppressive character of compulsory care.

At the same time, such democratic passion was incongruous with notions of the drug user as an enburdened slave, since drug users who had voluntarily consented to treatment and who were themselves responsible for getting better were expected to be rational citizens capable of making their own decisions. On a political level, this conflict paved the way for ideological argumentation, which removed the focus away from the individual drug users. All parties took up the opportunity in the parliament to sketch a picture in which drugs were seen as one of the biggest societal problems - 'more dangerous than the atom bomb' - and which therefore called for exceptional measures and strict sentences (Lower House Parliamentary Record I967:20, $\mathbb{1}$ I 4:25).

Regardless of assurances that the parliament should stand united in the drugs question - like 'a coalition government facing the threat of war' - the description of a catastrophic situation has enabled ideological posturing (PR 1996/97:94, $\mathbb{5}$ : I4). For example, the left has found that drug abuse could be explained by ' $\mathrm{t}$ ] he commercial youth culture and the increasingly brutal 
market economy' (Parliamentary Bill [PB] I997/98:So649:9; PB I 998/99:So258:3). The right-leaning parties have exhibited rather more conservative values and found the causes 'in our keen cadre of so-called cultural workers [who] purposely fight to wreck the homes' (PR I97I:I36, $\mathbb{S}$ I3:34). The representatives of these parties have seen how 'satanism, for example, in practice necessitated drugs, with grave desecrations, arson attacks on churches and even murders as a result' (PR I998/99:58, $\mathbb{S} 3: 4 \mathrm{f}$.).

In fact, no question has been too far-fetched to be linked to the mighty symbol of drugs. This can be illustrated by the Centre Party MP who, at the beginning of the I990s, strove to keep passenger traffic running on the railway line in the interior of northern Sweden. The argument was that discontinuing this traffic would lead to unemployment and thereby to drug abuse (Edman 2OI2). The railway line running through the north of Sweden may appear far removed from the most pressing drug problems, but not only does it prove the potent symbolic value of the drugs issue, it also helps us to see certain drug political contours. Here, the picture of the enslaving drugs has been neatly complemented by calls for penalties and compulsory care, while the symptom theorists have also been able to advocate social reforms ranging from class conflict to extended railway lines and tax cuts.

At the end of the I960s and the beginning of the I970s, the penalties for drug-related crime were tightened on a number of occasions, while the disease model of drug abuse was somewhat paradoxically more or less taken as a given. This is most clearly seen in the decision to locate the compulsory care of drug abusers to the psychiatric hospitals, which would not have been possible had drug abuse not been defined as a psychiatric disorder (Edman 2009). While the great social services reform was in the pipeline, compulsory care was also debated with renewed intensity. The social enquiry explicitly wielded these debates, which were also heard in the parliament, the daily press and in professional journals as well as in a range of shadow committees. Two organisations devoted to the issue of drug policy, the National Association for Aid to Drug Abusers (RFHL, Riksförbundet för hjälp åt läkemedelsmissbrukare, established in 1965) and the National Association for a Drug-free Society (RNS, Riksförbundet 
narkotikafritt samhälle, established in 1969) made it very clear where the lines of conflict were drawn. The former pleaded for reduced compulsory care, the latter wanted more of it. There were thus opposite trends on compulsory care and the penalty scale in the I970s. The coercive element was criticised in the care of alcohol abusers, and democratic forms of care and treatment were pressed for, but the tone remained harsh in the drug political debate and tougher sentencing made its way into the legislation. Both in the parliament and in the news, drugs were still among the greatest ills of Swedish society.

At the beginning of the I980s, the compulsory care of alcoholics and drug abusers was finally concentrated under one legislation. This had been a long road and shows the conceptual scope of the field. The repressive nature of the compulsory care of alcohol abusers was much resented - and such care also discriminated against the lower classes to a greater degree. The medicalisation of alcohol abuse would admittedly have harmonised the compulsory care of alcohol and drug abusers, who had been declared as suffering from a psychiatric disorder, but this harmonisation would also create a large group of potentially mentally ill consumers of a culturally accepted substance. The alternative, to give a clean bill of health to those drug abusers who had, since the late I 960 , been committed to compulsory care on medical grounds was not unproblematic, either.

After many years and a change of government (with new directives on the enquiry), the social enquiry proposed two contradictory alternatives, one advocating compulsory care on a social basis, the other preferring compulsory care on medical (psychiatric) grounds. This politically untenable solution with two incompatible variants of compulsory care put the social service reform on hold for some years, before a new enquiry was able to dismiss 'hard-to-define abstract concepts', such as dependence, as a basis for legally secure compulsory care (SOU I98I:7:38). This is why the new law on compulsory care, the Care of Abusers Act (Lag för vård av missbrukare, LVM), came to focus on the social grounds and indicators.

During a few odd years in the early I980s, there prevailed in Sweden the greatest convergence in the field of intoxication policy 
since it had been expanded to also cover the drug problem. The intensive I970s debate on the social services had placed both alcohol and drug abuse in a social context, often with symptom theoretical undertones. This was mirrored by the new legislation on compulsory care because it primarily applied to acute situations; making use of social grounds and social indicators, the law was intended to save lives and prevent serious illness. The number of people committed to compulsory care declined steadily, while the alcohol policy continued to rest on principles of solidarity, high taxes and limited availability. The availability was further limited by the decision in 1982 of the alcohol retail monopoly to keep the outlets closed on Saturdays.

The repressive drug policy, however, sent entirely different messages to the world than did the restrictive policies on alcohol. Towards the end of the I970s, the parliament had agreed on the challenging target that 'the society cannot accept any other use of drugs than that motivated by medical needs' (Governmental Bill I 977/78:105:30; SoU I977/78:36; PR 1977/78:160).59 Any other use was determined as abuse. At the beginning of the r 980 , the police also launched a campaign against small dealers instead of concentrating, as before, on the major drug criminals (Kassman I998). The late I980s also showed the first examples of a stricter care policy in conjunction with the revised law on compulsory care. The revisions were made to enable longer treatment periods and to broaden admissions criteria. Control policy was radicalised at the same juncture: not only the possession but also the use of drugs was criminalised. As of 1993, the penalty scale for this offence includes imprisonment. Previously, the drugs legislation had emphasised a difference between the drug users and drug dealers. As a result of the 1993 revision, both parties were defined as offenders (Träskman 20II).

At the same time, the alcohol policy was headed in the opposite direction, towards increased liberalisation. The development has not been straightforward; several liberalising reforms have been carried through under external pressure, mainly as a consequence

59 The definition of drug use as 'any non-medical use of drugs' is already found in the report by the commission on the care of drug users (SOU I967:25:22). 
of Sweden's membership in the EU since I995. Other measures are rather more homemade and are, as such, more indicative of the political will at home. That Sweden abolished four of the five alcohol-related monopolies and allowed unlimited import for private use can be considered as stemming from its entry into the EU. Sweden has, however, avoided the radical tax cuts introduced by, for example, Denmark and Finland.

The three pillars of the Swedish alcohol policy (limited availability through the state monopoly and age limits, heavy taxation and non-profit retail trade) can therefore, despite the external pressures, be described as intact yet weakened. The pillars have been made weaker still by the Saturday opening at the Systembolaget, which was brought back in 200I. From I992-2020, there has also been a marked liberalisation concerning the services for providing beverages: the number of permanent licences to serve alcohol has more than doubled (Folkhälsomyndigheten 202 ra).

\section{Conceptual Convergence}

The current divergence between alcohol and drug policies is a bit paradoxical given the common conceptual understanding of misuse problems as diseases, which once again grew stronger from the late twentieth century onwards. Somewhat simplified, one can argue that the alcohol political medicalisation has followed the established line of reasoning promoted by the post-war American alcoholism movement. This movement saw alcohol as a necessary, but by no means sufficient, factor behind those alcohol problems which mainly emerged among certain individuals (psychologically or genetically) predisposed to developing abuse problems. The trend is not yet as pronounced in Sweden - given the Swedish tradition of social alcohol policy - but it can be detected in commission enquiries and official documents, which appreciatively, or at the very least uncritically, take medicalised international concepts as their starting point (see, for example, Folkhälsomyndigheten 2018; Socialstyrelsen 2017).

Today, substance abuse treatment is typically referred to as dependency treatment, and the latest major public enquiry in $20 \mathrm{II}$ proposed that it should be possible to commit both alcohol and drug abusers to compulsory psychiatric care because it 'has been 
shown that abuse and dependency are considered as psychiatric diagnoses, which also clearly emerges from the international diagnostic and classification systems' (SOU 20II:35:307). The commission's proposal was not adopted, which in itself speaks volumes for the intoxicant political dissonance during the 2000s. It is no problem to officially describe alcohol and drug abuse as a medical addiction, but problems arise when the premise is to be put into practice. That the difference should be a matter of degree rather than an essential difference between an ordinary consumer of alcohol and a psychiatrically ill alcohol abuser is hard to digest in the Swedish alcohol political debate. Efforts to equate the culturally familiar figure of the alcohol abuser and the less familiar character of the drug abuser already failed at the end of the I970s, when the minority government, led by the Liberal Party, attempted this. On that occasion, the legislators put a definitive stop to committing substance abusers to compulsory psychiatric care 'whether they are mentally ill or not' (Lagrådets protokoll 27/2 I979:395 f.). The proposal by the public enquiry in 20 I I came under heavy criticism from several consultation bodies and was not addressed at a political level at all (Socialdepartementet 20I2).

Sweden has so far not taken the final step towards describing substance abuse as a primarily medical question, which is also seen in the fact that substance abuse problems are dealt with by both the municipal social services and within the health care system administered by the county councils. Such shared responsibility is rare in the EU. Alcohol abusers can admittedly be viewed as ill these days, which has long been the label used for drug abusers, at least in the political debate (and in Swedish political terminology any non-medical use of drugs makes a person a drug abuser). The extension of drug political harm reduction, which has come rather late in the day and has taken the form of substitution treatment and needle exchange programmes, is one of the more concrete examples of such medicalisation (Edman 20I7). Alcohol abuse is also increasingly treated with medical methods of varying effect.

Even if the social perspective continues to stand in good stead, both in legislation and politics, an internationally potent movement advocates a medicalised view on intoxication and related problems. The inspiration stems from the so-called Brain Disease 
Model of Addiction (BDMA), which seeks to explain an increasing range of human conditions and actions. The model also draws on general definitions of dependency, craving and abstinence to explain behaviours that have nothing whatsoever to do with intoxicants. These include such behavioural addictions as shopaholism and sex addiction (Edman \& Berndt 20I 8). This perspective is institutionalised in the interaction between influential diagnostic manuals and a rapidly growing research field with creative operationalisations of the diagnostic criteria (Edman \& Berndt 20I6).

The question is whether this broadened biomedical problem description could lead towards revitalised harmony within intoxication policy. For example, could the equation in a biomedical sense of alcohol and drugs pave the way for liberalised drug policies, which would deal with the disease of addiction with care and treatment instead of trying to contain it with penalties? One example of a more care-oriented approach comes from Portugal, where decriminalisation and major investments in addiction treatment have reduced drug-related morbidity and mortality (Hughes \& Stevens 2010). Norway, among others, has shown interest in changing its drug policy in line with the Portuguese model (Johnsen 20I7). So far, there are no real signs of Sweden following that path, even if we have seen some tendencies in that direction lately, with lawyers publicly advocating decriminalisation of drug use and a less confrontational media debate on drug issues (Avkriminalisera 20I9; Ekdal och Ekdal 20I9). At the time of writing, the Swedish parliament's social committee has also unanimously invited the government to evaluate the Swedish drug policy to make sure that it is 'consistent with the requirements of evidence-based care, proven experience and harm reduction', but it is also stated that any reform should take a 'continued restrictive drug policy' as its point of departure (SoU 2019/20:7: 29). In a rather blatant attempt to avert decriminalisation of drug consumption, the Swedish social minister has, however, preceded any evaluation by stating that decriminalisation is not on the agenda (Thurfjell 2020). Policy-based evidence still has the upper hand over evidence-based policy.

Things may happen, but at a slow pace. The diagnostic culture has united the field conceptually, but this has not yet led to any 
liberalisation of the Swedish drug policy. In the popular understanding of intoxication problems, addiction diagnoses of alcohol versus drug consumption also play rather different roles: the brain disease of narcomania is a challenging nightmare scenario, justifying repressive measures, while alcohol addiction fits in with the liberal alcohol policy and is the basis of voluntary treatment forms for a better-off clientele that should learn moderation rather than abstinence (Zaitzewsky Rundgren 20I3). This intoxication political dissonance also shows that this is still, to a great degree, a question of class politics. Drug policies were formulated in the I960s as an official response to the increasingly evident abuse of narcotics and medications. The working-class youth that gave a face to the drug problem served as a wry reflection of the diligent citizen, and much of the treatment also aimed at social rehabilitation and an orderly life (Edman \& Olsson 20I4). The care and treatment of alcohol abusers has provided this classbased education ever since the early I900s, and even today those committed to compulsory care are clearly a socioeconomically disadvantaged group ( $\mathrm{SiS}$ 2018). The trend is also seen in the public health-driven prevention work: for example, research within prevention science promotes individualised solutions to problems that could otherwise be construed as structural (Roumeliotis 2016). This understanding of the substance abuse problems neither hinders tougher sentencing for drug offences nor spoils a merry occasion of direct sales of alcohol by producers.

The post-war model of addiction has admittedly conceptualised alcohol as an unhealthy intoxicant, but the core of the phenomenon has been placed within certain alcohol users. While this solution satisfies the idea of care and treatment, it does not challenge the great alcohol-consuming public or strong capital interests. If the site of the dependence was the very substance instead, the political implications would be entirely different. This is, for instance, the case with tobacco, since nicotine addiction almost without fail has been discussed as a property of the substance. The very idea of there being a group of people predisposed to heavy tobacco use has, in fact, been condemned as 'ludicrous' by a researcher in this field (Nordlund 2005:337). The fact that we consume roughly the same amount of alcohol now as we did in the mid I970s, while 
smoking has declined radically, shows the importance of choosing the right explanatory model as policy support (Edman \& Berndt 2020). Drugs may have been banned long ago, but they share the tobacco model of addiction. If we avoid seeking consistency in the increasingly biomedicalised intoxication policy, it is perfectly possible that this dissonance will go on to thrive.

\section{Where Are We Heading?}

The different constructions of alcohol and drug use run like a red thread through what can be described as the dissonance of the Swedish intoxication policy. The recurring ambition to politically adopt an umbrella concept for intoxication, to find a lowest common denominator for the problem area, whether that be social inequality or medical dependence, has so far not led to equal treatment of alcohol and drug users. The political construction of the problem is much too distinct, which then drives radically different political control measures. At one point, alcohol was the dangerous intoxicant - so dangerous that it was almost prohibited. Since the I960s, the drugs have assumed this role and are often described as among the greatest social problems. The policy dissonance is, regardless of the conceptual harmonisation, evident in the latest governmental alcohol and drug strategy, for example. Even though it is acknowledged that the regulation of substances differs, alcohol and drug misuse are both described as dependency. However, the policy goals are divided: to 'limit the harm of alcohol' versus create a 'drug-free society' (Regeringens skrivelse 20I 5/I 6:86: 6 \& IO).

Where does this leave us, then; are drugs not vastly more dangerous than alcohol? A soiled heroin needle in a public toilet does, unarguably, appear riskier than a glass of rosé on a nice terrace. But how accurately do these stereotypical images portray the reality? 'Drugs' is a generic collective term for everything from khat and marijuana to crack and heroin. The reluctance in Swedish politics to divide narcotic preparations into light and heavy drugs masks this effectively. This is a part of the Swedish zero-tolerance policy on drugs, a political doctrine that has brought governments of various hues together since the I970s. The same zero tolerance has also bred a political reluctance to make a commitment 
to substitution treatment, needle exchange programmes and other efforts that could make the drugs less dangerous. These measures have therefore come late because of a fear of legitimising drug use: 'To give needles to drug addicts for free is like giving an alcoholic a bottle of whisky once a month in a spirit of rehabilitation', as a right-wing politician formulated it at the beginning of the $2000 \mathrm{~s}$ (PB 2005/06:So523).

Researchers tend to talk about control damage, that is, the damage and consequences caused by the ban and the repression itself, which are then often used as a pretext for tough and repressive measures. But it is possible, also without talking about control damage, to question the absolute hierarchy of harm that justifies long prison sentences for dealing light drugs while allowing ever more licences to serve alcohol in nice comfortable surroundings. According to the British neuropsychopharmacologist David Nutt, it is difficult, on the whole, to derive drug control from the harmful effects of the substances. He claims that it is not necessarily the most dangerous intoxicants that come under the most restrictions. Like Sweden, Great Britain has a relatively restrictive drug policy and a liberal alcohol policy. However, Nutt estimates that the harmful effects from alcohol and tobacco are higher than, for example, harms from cannabis, LSD and ecstasy (Nutt, King, Saulsbury \& Blakemore 2007). ${ }^{60}$ This message was emphasized when Nutt (2009), as the chair of the British government's Advisory Council on the Misuse of Drugs, scored rhetorical points by describing ecstasy as less harmful than horseback riding (or rather addiction to horseback riding, cleverly termed as 'equasy'). This did not lead to any revision of British drug policy but only to Nutt being sacked as chair of the council (Tran 2009). It is plainly obvious that culture and history, as well as downright prejudices about drugs and intoxicants, play a part in the legislation - also at a time when evidence is called for before political decisions are taken.

The weak relationship between an intoxicant's harmfulness and the societal responses to it have also been examined in a

60 A commission appointed by the British government had already found in I969 that alcohol was more harmful than cannabis, which was also reported in Sweden (see, for example, 'Cannabis ej lika farligt som alkohol', Dagens Nybeter, 9/I 1969). 
number of historical studies (e.g. Berridge 2013; Gusfield I996). It is, however, hard to appreciate various intoxicants' relation to injuries, mortality or dependence. Test methods and classifications change, estimates of necessary and sufficient causes of death are often problematic, diagnoses vary on the caregiver's skills and competences, traditions and financing models. Regardless of these difficulties, the official statistics can prove to be interesting and, even if for no other reason, can serve as a reasonable basis for political initiatives. According to the indicators employed by the Public Health Agency of Sweden (Folkhälsomyndigheten 20I9a; $2019 \mathrm{~b})$, more than double the number of Swedes died of alcohol-related causes in 2016 than did of drug-related causes (I907 and 908 individuals, respectively). Alcohol is deemed to be the fifth most common cause to the national burden of disease (calculated as premature disability and death). It ranks just behind smoking, but clearly before drugs, which are not even among the ten most common causes (GBD 20I7). While mortality and morbidity per user show a different picture, rational public health endeavours should perhaps also take these absolute figures as their starting point. But the discussion on whether intoxicants' harms should constitute the basis of intoxication policy has not had much of an impact on Swedish politicians.

Neither medicalisation nor discussion and contrasting of harms have led to any harmonisation of intoxication policies or, more importantly, to any liberalisation of the Swedish drug policy. This is not surprising since the drug question can hardly be reduced to a matter of fact, nor to any demonstrable relative harm where a one-dimensional critique of the disproportionality of drug policy would contribute to a collective awakening and cause our elected officials to change their opinion overnight. Rather, the drug issue is a matter of concern, with deep historical roots, broad social connotations, and firmly mixed with other political issues that go beyond instrumental reactions to drug consumption described as, for example, a public health problem. ${ }^{6 \mathrm{I}}$

6r For a critique of the critique of matters of facts vs matters of concern, see: Latour, B. (2004). Why has critique run out of steam? From matters of fact to matters of concern. Critical Inquiry, 3o(2), 225-248. 
Even within the narrower conceptual fields of understanding drug consumption as a disease, things get complicated because of the somewhat impressionistic use of the addiction model. Imprecise usage of key concepts within this model leads to a situation where this construction can legitimate a bit of anything, a dilemma that is older than the current brain-centred explanatory model. Already 50 years ago, the criminologist Nils Christie and the sociologist Kettil Bruun coined the term 'fat words' to refer to ambiguous concepts within the intoxication policy. They talked about drug addiction as one of these 'big, fat words without very much content' (Christie \& Bruun I969: 68). But these words served a role as 'grease in the social machinery', and provided an opportunity to avoid unpleasant political conflicts because they are 'camouflaging unsolvable dilemmas' (Christie \& Bruun I969: 7 I f.).

Two consequences emerge from this vague conceptual usage. Firstly, common and politically potent concepts do not always provide a satisfactory account of the actual conditions. Sometimes it is obvious that politics, in fact, shies away from concepts that describe the reality in a good way. For example, a public enquiry some years after Sweden's entry into the EU discussed the option of more often describing substance abuse as dependency - not because it corresponded to any verifiable qualitative trait, but because the term was commonly used outside Sweden and would therefore make comparative studies easier (SOU I 999:90).

Secondly, the pragmatic use of concepts shows that this area is hardly governable by research. The intoxication policy is influenced by a number of factors, and when it happens to be legitimated by research, it is often a case of carefully selected knowledge in support of certain political arguments. Evidence-based politics is still politics, and the step is therefore easy to take towards politics-based evidence. For example, the political opposition against needle exchange programmes was typically driven by arguments grounded in an ideologically based questioning of research or anecdotal reasoning for one's own case (Eriksson \& Edman 20I7).

The dynamic character of the drug issue as a multidimensional matter of concern, the vague and even contradictory conceptual framing, and the importance of the drug issue as a vital tool for 
various political discussions, all contribute to a drug political status quo. There are thus reasons to believe that the intoxication policy will only change in the face of strong forces. These could be political pressure groups fighting for drug user rights or politically useful problem descriptions or gains for the state. One strong new body of interest could be the market. A market-driven liberalisation is, however, not uncomplicated, nor logically necessary. As shown by Kleiman and Ziskind, legalisation of cannabis does not come in the form of a specific policy; it could be free or restrained, allowing marketing or not, drugs could be provided by for-profit or not-for-profit enterprises, in the form of a state monopoly, etc. According to the authors, a private, for-profit, vividly marketed solution - i.e. the US 'alcohol model' - would be 'the second-worst option (behind only continued prohibition)' (Kleiman \& Ziskind 2019:277).

Nevertheless, this is where we see the stronger initiatives for a change, as exemplified by Swedish alcohol liberalisations. Regardless of the recurring alcohol political ambition to wield restrictive alcohol policies, the concrete implementation shows with generous service licences and unlimited import for personal use, for example - a market-driven liberalisation. The proposed direct sales of alcohol by producers follow the market-oriented trend, when the reform is described as important for sparsely populated regions and the business sector. It is also clear that the direct sales are expected to appeal to a certain socioeconomic clientele. As a proponent of agrarian business interests expresses it, the direct sales seek 'the Swedish middle class [which] will grow increasingly inclined to spend money on really good-quality food and beverages' (Björklund 2017).

Is this market-driven liberalisation also the future for drug policies? If so, the alcohol industry surely has the money, and it is no coincidence that one of the biggest American alcohol producers has done deals within the newly legalised Canadian cannabis industry (Maloney \& George-Cosh 20I7). To allow this, however, there must be something in it for the state. In Canada and in the US states that have legalised cannabis, the expected tax revenues have clearly driven liberalised policies, and this is a plausible connection also on this side of the Atlantic (Colorado Department of 
Revenue, July 202I; Dehaas 2018; Kovacevich 2018). The great Finnish tax cuts on alcohol in 2004 were, for example, motivated, among other factors, by the desire to retain the tax revenue on alcohol sales, which the state risked losing otherwise (primarily to Estonia) (Mäkelä \& Österberg 2009).

In Sweden, too, the state is an important economic stakeholder, and irrespective of the daily-quoted market friendliness of the current government, there is an interest to direct the significant tax revenue from the sales of alcohol into the public treasury. The historical development of the Swedish tobacco and gambling market also shows that the national public health ambitions have hardly been devoid of crude financial interests (Edman \& Berndt 2020). The Swedish people will not be gifted any new tax-free sins.

The capital of intoxication is knocking at the door, and if we let it enter, it will be taxed, but the political price is the loss of an extremely potent symbolic issue. This is not just the problem of the year, soon to be replaced by another problem, as columnist Art Buchwald (I970) wittingly described the changing value of social problems. Sure, there are other problems aspiring to be the problem with a capital P in the 2020 - e.g. terrorism, migration or the environment - but the drug problem has served us well. Judging by the parliamentary debates since the mid I960s, drug use can be explained by almost anything. The solution is therefore sought far and wide. Whether one wants to lower taxes or maintain a railway, the drug problem becomes politically useful in a way that alcohol no longer can (Christie \& Bruun I985; Edman 2012). It will be hard to replace such a problem.

\section{References}

Alkoholismen är ej att betrakta som en sjukdom. (I927). Stockholms-Tidningen, 24/2.

Berridge, V. (20I3). Demons: Our changing attitudes to alcohol, tobacco, \& drugs. Oxford: Oxford University Press.

Björklund, H. M. (20I7). Uppblåst om gårdsförsäljning. ATL Lantbrukets affärstidning, I 2/9.

Book of Proverbs 3I:5 and 3I:7. 
Buchwald, A. (I970). Crowning a year's problem. The Sunday Missoulian, I/3.

Cannabis ej lika farligt som alkohol. (I969). Dagens Nybeter, 9/I.

Christie, N. \& Bruun, K. (I 969). Alcohol problems: The conceptual framework. In M. Keller \& T. G. Coffey (Eds.), Proceedings of the 28th International Congress on Alcohol and Alcoholism. Vol. 2, Highland Park, N.J.: Hillhouse Press.

Christie, N. \& Bruun, K. (I985). Den gode fiende. Narkotikapolitikk i Norden. Oslo: Univ.-forl.

Colorado Department of Revenue (202 I, July I I). Marijuana Tax Reports, https://cdor.colorado.gov/data-and-reports/marijuana -data/marijuana-tax-reports.

De Basso, Sargon et al. (20I9). Avkriminalisera bruk av narkotika i Sverige. Aftonbladet, $30 / \mathrm{I}$.

Dehaas, J. (2018). Provinces raked in revenue on day one of cannabis sales. CTV News, I8/ıо.

Edman, J. (2004). Torken. Tvångsvården av alkoholmissbrukare i Sverige I940-I98 I. Stockholm: Almqvist \& Wiksell International.

Edman, J. (2009). Vård till varje pris. Den psykiatriska tvångsvården av narkotikamissbrukarna I968-I98I. Stockholm: Stockholms universitet, Centrum för socialvetenskaplig alkohol- och drogforskning.

Edman, J. (201 2). Vård och ideologi. Narkomanvården som politiskt slagfält. Umeå: Borea.

Edman, J. (20I 5). Temperance and modernity. Alcohol consumption as a collective problem I885-I9I3. Journal of Social History, 49(I), 20-52.

Edman, J. (20I6a). Alkoholen som katalysator. Ikaros, I3 (I-2), I7-I9.

Edman, J. (20I6b). Harm to others - rediscovered or eternal? Nordic Studies on Alcohol and Drugs, 33(5-6), 479-48I.

Edman, J. (2016c). Transnational nationalism and idealistic science: The alcohol question between the wars. Social History of Medicine, 29(3), 590-610. 
Edman, J. (20I7). Swedish drug policy. In R. Colson \& H. Bergeron (Eds.), European Drug Policies: The Ways of Reform. New York: Routledge, I95-205.

Edman, J. (20I8). Un siècle de restrictions sur l'alcool: Un regard international et historique. In A. Coutant (Ed.), Prohibitions. Broché: Mare \& Martin, I I I-I39.

Edman, J. (20I9). Drogerna: Den nya berusningspolitiken. In J. Björkman \& P. Hadenius (Eds.), Det nya Sverige. Göteborg, Stockholm: Makadam Förlag.

Edman, J. (2020). A medical challenge: The alcohol disease in Sweden I946-I955. Social History of Medicine, 33(I), 224-246.

Edman, J. \& Berndt, J. (2016). From boredom to dependence: The medicalisation of the Swedish gambling problem. Nordic Studies on Alcohol and Drugs, 33(I), 8I-I Io.

Edman, J. \& Berndt, J. (2018). Oniomaniacs: The popular framing of consumption as a disease. Addiction Research \& Theory, $26(6), 43 \mathrm{I}-438$.

Edman, J. \& Berndt, J. (2020). A thickening plot: Components and complexities in the political framing of the smoking problem in Sweden, 1957-1993. Drugs: Education, Prevention and Policy, $27(2)$, I $45-153$.

Edman, J. \& Olsson, B. (20I4) The Swedish drug problem: Conceptual understanding and problem handling I 839-20I I. Nordic Studies on Alcohol and Drugs, 3I (5-6), 503-526.

Ekdal och Ekdal. (2019, February I9). Drogpolitiken. SVT. https:// www.svtplay.se/ekdal-och-ekdal.

Engels, F. (I 845). Die Lage der arbeitenden Klasse in England. Leipzig: Ej kursiverat. Wigand.

Eriksson, L. \& Edman, J. (20I7). Knowledge, values, and needle exchange programs in Sweden. Contemporary Drug Problems, 44(2), I05-I 24 .

Fattigvårdlagstiftningskommittén. (I9I I). Förslag till lag om behandling af alkoholister. Stockholm: Fattigvårdslagstiftningskommittén. 
Folkhälsomyndigheten. (202 Ia, October I I). Antal stadigvarande serveringstillstånd, I992-20I7. https://www.folkhal somyndigheten.se/folkhalsorapportering-statistik/statistik databaser-och-visualisering/alkoholdrycksstatistik-i-siffror/antal -stadigvarande-serveringstillstand/.

Folkhälsomyndigheten. (202 Ib, October I I). Socioekonomiska skillnader i alkohol, narkotika och tobak - delvis olika mönster för beroende och utsatthet. https://www.folkhalsomyndigheten .se/publicerat-material/publikationsarkiv/s/socioekonomiska -skillnader-i-alkohol-narkotika-och-tobak--delvis-olika-monster -for-beroende-och-utsatthet/.

Folkhälsomyndigheten. (2019a, January 29). Dödlighet enligt alkoholindex. https://www.folkhalsomyndigheten.se/folkhal sorapportering-statistik/folkhalsans-utveckling/halsa/dodlighet -enligt-alkoholindex/.

Folkhälsomyndigheten. (20I9b, January 29). Narkotikarelaterad dödlighet. https://www.folkhalsomyndigheten.se/folkhal sorapportering-statistik/folkhalsans-utveckling/halsa/narkotikare laterad-dodlighet/.

GBD 2016 Risk Factors Collaborators. (2017). Global, regional, and national comparative risk assessment of 84 behavioural, environmental and occupational, and metabolic risks or clusters of risks, I990-2016: A systematic analysis for the Global Burden of Disease Study 2016. The Lancet, 390, I345-I422.

Governmental Bill I977/78:I05. https://data.riksdagen.se/fil /CoA484 IE-2798-4E2A-9B9D-3 ${ }_{46} \mathrm{FB}_{5} \mathrm{~F}_{6} \mathrm{DBB}_{5} \mathrm{O}$.

Gusfield, J. R. (I996). Contested meanings: The construction of alcohol problems. Madison, Wis.: University of Wisconsin Press.

Hughes, C. E. \& Stevens, A. (2010). What can we learn from the Portuguese decriminalization of illicit drugs? The British Journal of Criminology, 50(6), 999-1022.

Johnsen, A. B. (20I7). Historisk i Stortinget: Slutt på straff for rusmisbrukere. Verdens Gang, I3/I 2.

Kassman, A. (I998). Polisen och narkotikaproblemet. Från nationella aktioner mot narkotikaprofitörer till lokala insatser för att störa missbruket. Stockholm: Almqvist \& Wiksell International. 
Kleiman, M. A. R. \& Ziskind, J. (20I9). Lawful access to cannabis: Gains, losses and design criteria. Journal of Illicit Economies and Development, I(3), 272-278.

Kovacevich, N. (2018). Cannabis is a tax bonanza for states. Forbes, 5/I 2 .

Lagrådets protokoll 27/2 I979. In Prop. I979/80: I, part B. https://data.riksdagen.se/fil/A 3 CF8oE6-E66E-438 5-8BFE-9 I 6 E8 $\mathrm{BBF}_{223}$.

Latour, B. (2004). Why has critique run out of steam? From matters of fact to matters of concern. Critical Inquiry, 30(2), 225-248.

Levine, H. G. ( 1978 ). The discovery of addiction: Changing conceptions of habitual drunkenness in America. Journal of Studies on Alcohol, 39(I), I43-I74.

Lower House Parliamentary Bill I944:3 Io (SKP). https://weburn .kb.se/riks/tv\% C $_{3} \%$ A 5 kammarriksdagen/pdf/web/I944/web _mot_I944_ak_3 Io/mot_I944_ak_3 Io.pdf.

Lower House Parliamentary Record I967:20, $\mathbb{S} 4$ (H). https:// weburn.kb.se/riks/tv\% $\mathrm{C}_{3} \% \mathrm{~A}_{5}$ kammarriksdagen/pdf/web/I967 /web_prot_I967_ak_20/prot_I967_ak_20.pdf.

Lundquist, G. R. (1983). Magnus Huss - pionjären inom svensk alkoholforskning. Alkohol och narkotika, 77(6), I8-23.

Mäkelä, P. \& Österberg, E. (2009). Weakening of one more alcohol control pillar: A review of the effects of the alcohol tax cuts in Finland in 2004. Addiction, IO4(4), 554-563.

Maloney, J. \& George-Cosh, D. (20I7). Big brewer makes a play for marijuana beverages. The Wall Street Journal, 29/ıO.

McCandless, P. (I984). 'Curses of civilization': Insanity and drunkenness in Victorian Britain. British Journal of Addiction, 79(4), 49-58.

McLaughlin, P. (1989) Responding to drunkenness in Scottish society: A socio-historical study of responses to alcohol problems. University of Stirling.

Nordlund, A. (2005). Tobaksrökning och hälsa i Sverige under I900-talet. In J. Sundin, C. Hogstedt, J. Lindberg \& H. Moberg 
(Eds.), Svenska folkets hälsa i historiskt perspektiv. Stockholm: Statens folkhälsoinstitut.

Nutt, D. (2009). Equasy - an overlooked addiction with implications for the current debate on drug harms. Journal of Psychopharmacology, 23(I), 3-5.

Nutt, D., King, L. A., Saulsbury, W. \& Blakemore, C. (2007). Development of a rational scale to assess the harm of drugs of potential misuse. The Lancet, 369(9566), I047-1053.

Parliamentary Bills [PB] I997/98:So649 (V) https://www.riksdagen .se/sv/dokument-lagar/dokument/motion/droger_GLo2So649; I 998/99:So258 (V) https://www.riksdagen.se/sv/dokument-lagar /dokument/motion/drogpolitiken_GMo2So258; 2005/06:So5 23 (KD) https://data.riksdagen.se/fil/IAF I $982 \mathrm{~F}-\mathrm{BD}$ IE-4DEB-AoAF -EI726EB470I 2.

Parliamentary Records [PR] I97I:I36 https://data.riksdagen.se/fil /EDo8B9E8-oB 5 5-4A 53-9DBI-ID8A76B I I 530; I 977/78: I60; I 996/97:94 https://data.riksdagen.se/fil/E3592D 47-EAo9-4E37 -8B53-2FFDB964I 5 A6; I998/99:5 8 https://data.riksdagen.se/fil /BoBB7 I 83-oDEF-42A6-934C-49 ICD7 I 470 ID; 20 I 7/I 8: I07 https://data.riksdagen.se/fil/9D ${ }_{\text {I }}{ }_{I} \mathrm{CDE}-498 \mathrm{~F}-4622-\mathrm{B} 6 \mathrm{E} 8$ -AiCi I 6675 I 39.

Regeringens skrivelse 20I 5/I6:86: En samlad strategi för alkohol-, narkotika-, dopnings- och tobakspolitiken 20I6-2020. https:// www.regeringen.se/49 Iaa I/contentassets/ocb3c9b3 b28b $49678 a_{7205} a_{3} 672 b_{3}$ e8 5/en-samlad-strategi-for-alkohol --narkotika--dopnings--och-tobakspolitiken-20I 62020-skr.-20 5 _I6-86.pdf.

Roumeliotis, F. (20I6). Ideological closure: Drug prevention in a post-political society. Stockholm: Department of Sociology, Stockholm University.

Schrad, M. L. (2007). The prohibition option. Transnational temperance and national policymaking in Russia, Sweden and the United States. University of Wisconsin-Madison.

Schrad, M. L. (20I0). The political power of bad ideas: Networks, institutions, and the global prohibition wave. Oxford: Oxford University Press. 
SiS (2018). Personer intagna på SiS LVM-hem 20I7. Statens institutionsstyrelse. https://www.stat-inst.se/webbshop/3-20I 8-personer -intagna-pa-sis-lvm-hem-20I $7 /$.

Socialdepartementet (2012). dnr S2OI 2/4504/FST.

Socialstyrelsen (20I7). Nationella riktlinjer för vård och stöd vid missbruk och beroende: vetenskapligt underlag.

SoU I977/78:36.

SoU 20I9/20:7.

SOU I948:23, Betänkande med förslag till lag om nykterhetsvård m.m.

SOU I 967:25, Narkotikaproblemet. Del I: Kartläggning och vaird.

SOU I967:36, Nykterhetsvårdens läge. Del I. Klientel och behandlingsresurser.

SOU I967:37, Nykterhetsvårdens läge. Del II. Bilagor.

SOU I967:4 I, Narkotikaproblemet. Del 2: Kontrollsystemet.

SOU I969:52, Narkotikaproblemet. Del 3: Samordnade åtgärder.

SOU I969:53, Narkotikaproblemet. Del 4: Socialmedicinska och kliniska undersökningar.

SOU I974:39, Socialvården. Mål och medel.

SOU I977:40, Socialtjänst och socialförsäkringstillägg. Lagar och motiv.

SOU I98 I:7, Lag om vård av missbrukare i vissa fall.

SOU I 999:90, Narkotikastatistik - om sambällets behov av information om narkotikastatistik.

SOU 2009:22, En ny alkohollag.

SOU 20I I:35, Bättre insatser vid missbruk och beroende.

Statement of Government Policy (2019, January I). https://www .regeringen.se/48f68a/contentassets/6eo630547665482eaf $982 \mathrm{c}_{4} 777 \mathrm{f}_{4} 2 \mathrm{f} 85 /$ regeringsforklaringen-2019.pdf.

Swedish Radio 5/I 2 201 8, https://sverigesradio.se/sida/artikel .aspx?programid=83 \&artikel $=7$ I06046. 
Thurfjell, K. (2020). S-ministern: Inte aktuellt med avkriminalisering. Svenska Dagbladet, I4/2.

Tran, M. (2009). Government drug adviser David Nutt sacked. The Guardian, 30/ıо.

Träskman, P. O. (20I I). Narkotikabrotten och kontrollen av bruket av narkotika genom straffrättsliga medel. In B. Olsson (Ed.), Narkotika. Om problem och politik, Stockholm: Norstedts Juridik.

Utkast till sakpolitisk överenskommelse mellan Socialdemokraterna, Centerpartiet, Liberalerna och Miljöpartiet de gröna, I I/I 2019.

White, W. L. (2004). The lessons of language: Historical perspectives on the rhetoric of addiction. In S. W. Tracy \& C. J. Acker (Eds.), Altering American consciousness. The history of alcohol and drug use in the United States, I800-2000. Amherst, MA: University of Massachusetts Press.

Williams, S. E. (I987). The attitude of physicians towards alcoholism in the U.S. from I790-I 860. In S. Barrows, R. Room \& J. Verhey (Eds.), The social history of alcohol. Drinking and culture in modern society. Berkeley, CA: Alcohol Research Group, Medical Research Institute of San Francisco.

Yokoe, R. (20I9). Alcohol and politics in twentieth-century Britain. The Historical Journal, 62(I), 267-287.

Zaitzewsky Rundgren, M. (20I3). Många alkoholberoende kan lära sig dricka måttligt. Accent, I 5/I I. 